\title{
Kemijski sastav ploda maraske u klimatski dvije različite godine
}

\section{Sažetak}

Višnja maraska (Prunus cerasus var. Marasca) jedna je od najznačajnijih voćnih vrsta Dalmacije, još od 16 stoljeća od kada datira i proizvodnja poznatog likera Maraschino. Areal rasprostranjenosti maraske ograničen je uglavnom na dio područja sjeverne i srednje Dalmacije od Zadra do Makarske, gdje klima $i$ tlo omogućuju postizanje visoke kvalitete ploda i specifične arome. Provedena istraživanja imala su za cilj utvrditi fizikalno-kemijske parametre (ukupnu suhu tvar, vodotopivu suhu tvar, ukupnu kiselost, udio mesa $i$ koštica), ukupne polifenole i antocijane te antioksidativni kapacitet u plodu višnje maraske u dvije klimatski različite godine (2012 i 2013), na plantaži "Vlačine" (Zadar). Značajno veće vrijednosti ukupne suhe tvari, ukupnih polifenola i antioksidativnog kapaciteta utvrđene su u 2012., dok su veće vrijednosti ukupnih kiselina i antocijana utvrđene u 2013. godini, što se može dovesti u svezu s većim količinama oborina i nižim temperaturama u fazi zriobe plodova u 2013. godini. Značajno niže vrijednosti antocijana u 2012. u odnosu na 2013. godinu mogu se objasniti ekstremno visokim temperaturama u fazi zriobe u 2012. godini, koje prema literaturnim navodima mogu smanjiti količinu antocijana i do $90 \%$. U obje godine istraživanja utvrđena je pozitivna korelacija između ukupnih polifenola i antocijana, što potvrđuje činjenicu da su antocijani dominantni polifenolni spojevi u plodu maraske.

Ključne riječi: plod maraske, klimatske prilike, polifenoli, antocijani, antioksidativni kapacitet

\section{Uvod}

Višnja maraska (Prunus cerasus var. Marasca) u Dalmaciji se uzgaja više od pet stoljeća. Kroz povijest njezino ime se najviše povezuje uz liker Maraschino, čija proizvodnja datira s početka 16. st. Prema pomološkoj klasifikaciji ubraja se u višnje malog lista, obojanog soka i mekanog mesa (Vrsaljko, 2010). Njen je uzgoj povijesno ograničen na područje srednje i sjeverne Dalmacije, od Makarske do Zadra, uključujući otoke Brač i Hvar, te u Dalmatinskoj zagori, područje oko Sinja i Drniša te područje Benkovca (Medin, 1971). lako se maraska može uzgajati i u hladnim krajevima te na većim nadmorskim visinama, kvalitetu ploda, tj. visoki sadržaj suhe tvari i šećera, te svoju specifičnu aromu postiže samo u toplijim i sušim krajevima, do pretežno 200 metara nadmorske visine (Medin, 1989). Nutritivna i biološka svojstva ploda formirana su količinom i odnosom među komponentama kemijskog sastava (organski i anorganski spojevi). Na kemijski sastav ploda pored genetskih karakteristika, značajan utjecaj ima geografsko područje, agrotehničke i agrokemijske mjere i zahvati, uvjeti dozrijevanja, transport, skladištenje, obrada i stupanj zrelosti te klimatske značajke područja (Pedisić $i$ sur., 2007). Maraska ima veću ukupnu kiselost, puno veći udio suhe tvari (17-26\%) te nešto veći udio ukupnih šećera (11-16\%) u odnosu na druge sorte višanja, ovisno o klimatskim uvjetima u vrijeme zriobe. Prema Ćosiću (1993), pH vrijednost maraske je oko 3,5. Zbog visokog sadržaja vitamina, minerala te naročito polifenola među kojima se ističu antocijani, smatra se voćem visoke biološke vrijednosti koje ima izražena antioksidacijska, antimikrobna, antikancerogena i druga svojstva (Dragović-Uzelac, 2007). Crvena boja ploda maraske potječe od biljnih pigmenata antocijana, polihidroksi spojeva

Prof. dr. sc. Lepomir Čoga, Vesna Jurkić, mag. ing. agr., Dr. sc. Sanja Slunjski,

Sveučilište u Zagrebu Agronomski fakultet, Svetošimunska 25, 10000 Zagreb, sslunjski@agr.hr

Dr. sc. Silvija Zeman, Međimursko veleučilište u Čakovcu, Bana J. Jelačića 22 a, 40000 Čakovec

Ante Jurkić, student, II Maksimirsko naselje 5, 10000 Zagreb 
koji se u prirodi nalaze u obliku glikozida (Dekazos, 1970). Antocijani pripadaju flavonoidnoj grupi polifenola. To su glikozilirani polihidroksi i polimetoksi derivati 2-fenilbenzopirilium kationa, odnosno flavilium kationa (Brouillard, 1982). Antocijani se nalaze u mesu i kožici ploda te se koriste kao glavni indikatori dozrijevanja ploda višnje maraske i ostalog crvenog voća (Chandra,1993). U maraski su najzastupljeniji antocijani cijanidin-3-glukozilrutinozid i cijanidin-3-rutinozid, a slijede glikozidi pelargodina i to pelargodin-3-glukozid i pelargodin-3-rutinozid, dok su u manjim koncentracijama određeni peonidin-3-glukozid i peonidin-3-rutinozid (Pedisić i sur., 2010).

Agroekološki čimbenici kao što su insolacija i temperatura vrlo su važni za razvijanje crvenog pigmenta u voću (Saure, 1990). Kvaliteta ploda maraske uvelike ovisi o stadiju zrelosti i usko je vezana s antocijanom i ostalim bioaktivnim tvarima koje se mijenjaju tijekom dozrijevanja. Polifenoli i ukupni antocijani smatraju se dobrim indikatorima antioksidativnog kapaciteta. Prema istraživanjima, postoji velika korelacija između antioksidativnog kapaciteta i ukupnih polifenola. Na antioksidativni kapacitet crvenih plodova (pa tako i višnje maraske) utječe sadržaj ukupnih antocijana (Dragović-Uzelac i sur., 2009). Osim polifenolnih spojeva, istraživanja su pokazala da višnja u značajnoj koncentraciji (otprilike 3,5 $\mathrm{ng} / \mathrm{g}$ ) sadrži i biljni hormon melatonin. On također pokazuje antioksidativna svojstva, ali i regulira proces spavanja, usporava proces starenja stanica, te ima protuupalni učinak (Burkhardt i sur., 2001). Antioksidansi imaju zaštitnu ulogu u obrani biljne hrane od slobodnih radikala koji oksidiraju nukleinske kiseline, proteine, lipide ili DNA. Glavna karakteristika antioksidansa je mogućnost zarobljavanja slobodnih radikala koji bi mogli oksidirati nukleinske kiseline, proteine, lipide ili DNA (Dragović-Uzelac i sur., 2007). Plod maraske bogat je i nehlapljivim aromatičnim tvarima, organskim kiselinama (miristinska, palmitinska, stearinska, oleinska), bojama, aminokiselinama, mineralima (Ca, P, Fe) i vitaminima.

\section{Materijal i metode}

Istraživanja kemijskog sastava ploda maraske provedena su 2012. i 2013. godine na plantaži „Vlačine“ (Maraska d.d.), površine 200 ha, podignutoj 2005-2006 godine. Na najvećem dijelu nasada, na skeletnim i skeletoidnim tlima (cca $180 \mathrm{ha}$ ) kao podloga za marasku korišten je sjemenjak rašeljke (Prunus mahaleb) iz ravničarskog dijela (Mađarska), dok je na manjem dijelu površine (cca 20 ha), na dubokoj crvenici kao podloga korištena višnja (Prunus cerasus). Najzastupljeniji klonovi u nasadu su Brač 6 (cca 70 \%) na kojem su i provedena istraživanja te Sokoluša. $U$ obje godine istraživanja osnovna gnojidba provedena je $s 400 \mathrm{~kg} / \mathrm{ha}$ NPK 5:15:30+B. Polovina navedene količine primijenjena je $u$ jesenskom razdoblju, a druga polovina koncem veljače. Prihrana dušičnim gnojivima provedena je u ožujku s $150 \mathrm{~kg} / \mathrm{ha}$ uree.

Kemijski sastav ploda maraske određen je u ukupno 40 prosječnih uzoraka (20 uzoraka 2012. godine, te 20 uzoraka 2013. godine, uzetih po istoj shemi uzorkovanja), slika 1. Svaki prosječni uzorak predstavljala je homogena smjesa od $5 \mathrm{~kg}$ ploda, a formiran je od 30 pojedinačnih uzoraka uzetih $\mathrm{s}$ istih 30 stabala, svake godine. Priprema uzoraka za kemijsku analizu i određivanje ukupne suhe tvari, vodotopive suhe tvari, ukupnih kiselina te udio mesa i koštice u plodu maraske provedeno je u laboratoriju Zavoda za ishranu bilja (Sveučilište u Zagrebu Agronomski fakultet), slika 2. Određivanje ukupne suhe tvari provedeno je sušenjem na $105^{\circ} \mathrm{C}$, a ukupna vodotopiva suha tvar određena je refraktometrijski. Ukupne kiseline određene su metodom koja se temelji na potenciometrijskoj titraciji otopinom natrijevog hidroksida (Pravilnik, 1983). Udio koštica i mesa određen je u $100 \mathrm{~g}$ ploda za svaki prosječni uzorak. 


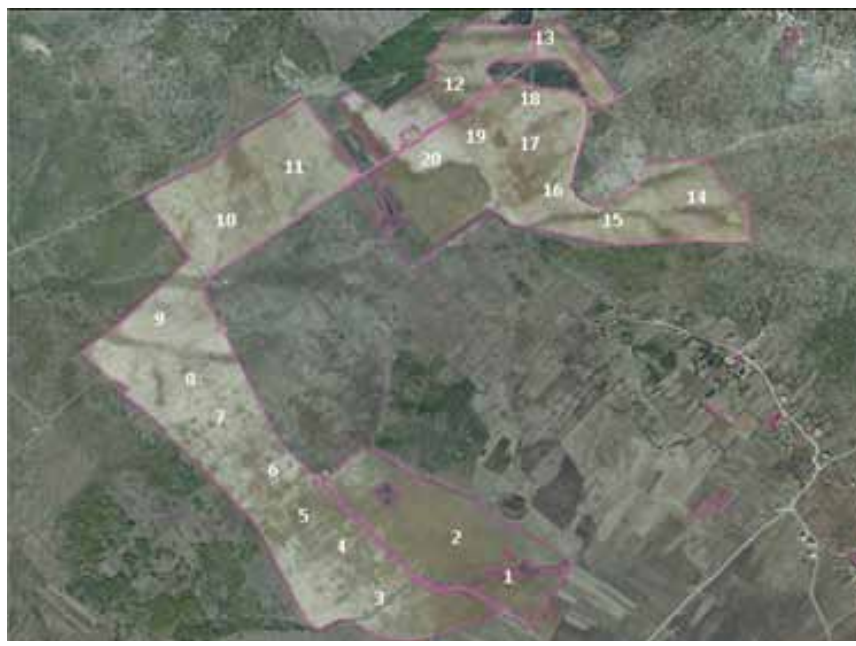

Slika 1. Prostorni raspored uzimanja uzoraka

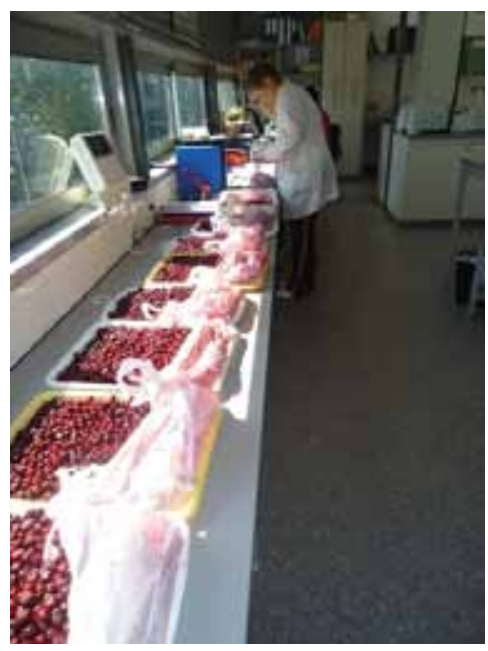

Slika 2. Analiza ploda maraske

Kemijske analize plodova izvršene su na Prehrambeno biotehnološkom fakultetu u Zagrebu, u etanolnom ekstraktu $\left(\Psi\left(\mathrm{EtOH}, \mathrm{H}_{2} \mathrm{O}\right)=4,0\right.$; reflux $)$ usitnjenog ploda višnje Maraske očišćenog od koštica. Ukupni polifenoli određeni su spektrofotometrijski Folin-Ciocalteuovom metodom i izraženi kao ekvivalenti galne kiseline u $100 \mathrm{~g}$ jestivog dijela ploda (Ough i Amerine, 1988). HPLC elucijski profil polifenola određen je u metanolnom ekstraktu ( $\Psi$ $\left.\left(\mathrm{MeOH}, \mathrm{H}_{2} \mathrm{O}\right)=4,0\right)$ usitnjenog ploda maraske očišćenog od koštica. Primijenjena je gradijentna elucija (A: $\left.0.5 \% \mathrm{H}_{3} \mathrm{PO}_{4} / \mathrm{H}_{2} \mathrm{O}, \mathrm{B}: \mathrm{MeOH}: \mathrm{MeCH}=1: 1\right)$ na reverznofaznoj (C-18) koloni, uz UV-VIS detekciju pri 280, 320, 370 i $520 \mathrm{~nm}$.

Za određivanje antioksidativnog kapaciteta (TEAC) korištena je ABTS metoda (Arnao $i$ sur., 2001). U ovoj se metodi prati raspadanje radikala ABTS (vrijeme reakcije: $180 \mathrm{~s}$ ), koji nastaje oksidacijom 2,2-azinobis (3-etilbenzotiazilin-6-sulfonat) djelovanjem fenolnih tvari. $U$ odsutnosti fenolnih tvari, $A B T S$ je relativno stabilan, ali brzo reagira u prisustvu donora $\mathrm{H}^{+}$te prelazi u neobojeni oblik ABTS-a. Rezultati su iskazani kao milimoli Troloxa (vodotopljivog oblika vitamina E) u $100 \mathrm{~g}$ jestivog dijela ploda. Ukupni antocijanini određeni su spektrofotometrijski metodom po Giusti i Wrolstadu (2001), a rezultati su izraženi kao ekvivalentna masa cijanidin-3-glukozida u $100 \mathrm{~g}$ jestivog dijela ploda.

\section{Klimatske prilike u 2012. i 2013. godini \\ Oborine}

Godišnje i mjesečne količine oborina u 2012. i 2013. godini analizirane su na temelju podataka s mjerne postaje Zadar-aerodrom (Zemunik), koja se nalazi u neposrednoj blizini plantaže „Vlačine“. Ukupna količina oborina u 2012. godini $(798,1 \mathrm{~mm})$ bila je nešto niža od 25-godišnjeg prosjeka za razdoblje 1981-2005 (859,7 mm), a značajno niža od količine oborina $(1161,8 \mathrm{~mm})$ utvrđenih u 2013. godini. U odnosu na ukupne količine oborina, još veće razlike utvrđene su u mjesečnim količinama oborina (graf 1 ), a to se posebno odnosi na mjesečne količine oborina u prvih šest mjeseci (graf 2). 


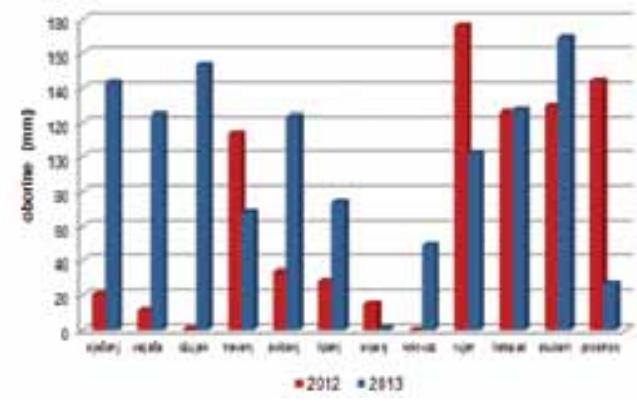

Graf 1. Količine oborina (2012-2013) po mjesecima

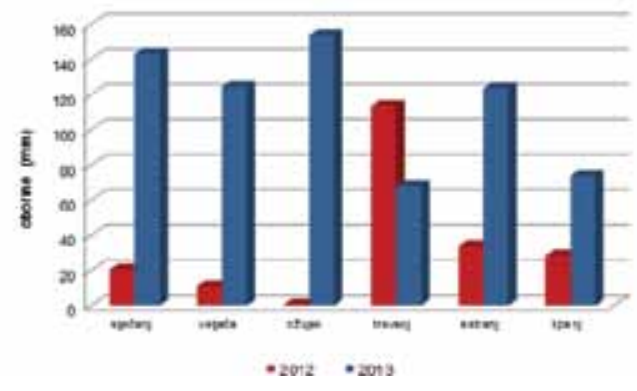

Graf 2. Oborine u prvih šest mjeseci (2012-2013)

U prvih šest mjeseci u 2012. godini palo je svega $207,9 \mathrm{~mm}$, a u 2013. godini čak 725,7 $\mathrm{mm}$ oborina. Analizom rasporeda oborina utvrđeno je da je u prvih šest mjeseci u 2012. palo svega $26,0 \%$, a u 2013. godini čak $60,4 \%$ od ukupne količine oborina. U usporedbi s 25-godišnjim (1981-2005) prosjekom mjesečnih količina oborina za MP Zemunik na kojoj je izmjereno da u prvih šest mjeseci padne oko $45 \%$, a u drugom dijelu godine $55 \%$ ukupnih količina oborina, može se zaključiti da je odnos između godišnjih i mjesečnih količina oborina značajno odstupao u obje godine istraživanja.

\section{Temperatura zraka}

Srednje temperature zraka u 2012. i 2013. godini po mjesecima prikazane su na grafu 3. Srednje mjesečne temperature zraka u prvih šest mjeseci u 2012. godine kretale su se od $2,7^{\circ} \mathrm{C}$ (veljača) do $24,1^{\circ} \mathrm{C}$ (lipanj), a u 2013 . godini od $5,8^{\circ} \mathrm{C}$ (veljača) do $21,1^{\circ} \mathrm{C}$ (lipanj), graf 4. Prema toplinskim oznakama riječ je o umjereno toploj klimi.

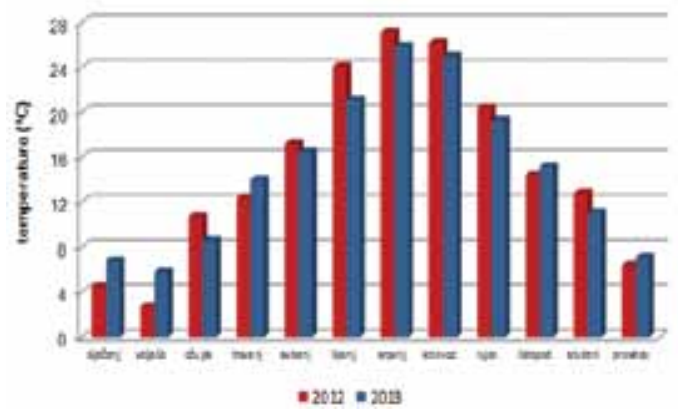

Graf 3. Srednje temp. zraka (2012-2013) po mj.

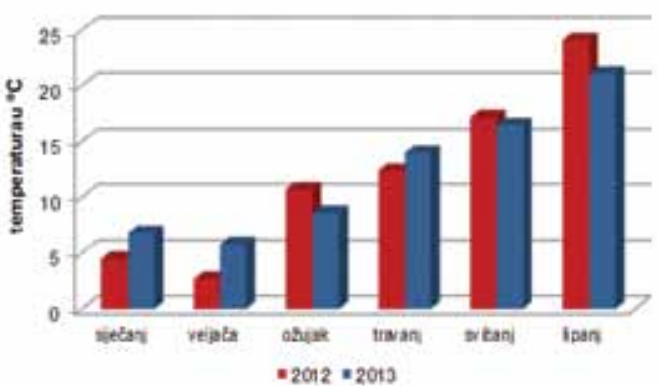

Graf 4. Srednje temp. zraka u prvih $6 \mathrm{mj}$. (2012-2013)

Iz grafa 3 razvidno je da su najhladniji mjeseci u obje godine istraživanja bili siječanj i veljača, što je u skladu s 25-godišnjim prosjekom mjesečnih temperatura za MP Zemunik koja za siječanj i veljaču iznosi 5,0 odnosno $5,3^{\circ} \mathrm{C}$, s kolebanjima srednje mjesečne temperature od $2,8-8,2^{\circ} \mathrm{C}$. 


\section{Rezultati i rasprava}

Rezultati fizikalno-kemijskih značajki ploda maraske na plantaži „Vlačine“ (Maraska d.d.) prikazani su u tablici 1.

Tablica 1. Fizikalno - kemijska svojstva ploda maraske, 2012-2013

\begin{tabular}{ccccccccc}
\hline & \multicolumn{2}{c}{$\begin{array}{c}\text { Ukupna suha } \\
\text { tvar (\%) }\end{array}$} & \multicolumn{2}{c}{$\begin{array}{c}\text { Vodotopiva suha } \\
\text { tvar (\%) }\end{array}$} & \multicolumn{2}{c}{$\begin{array}{c}\text { Ukupne } \\
\text { kiseline (\%) }\end{array}$} & \multicolumn{2}{c}{$\begin{array}{c}\text { Udio mesa u } \\
\text { plodovima (\%) }\end{array}$} \\
\hline godina & $\mathbf{2 0 1 2}$ & $\mathbf{2 0 1 3}$ & $\mathbf{2 0 1 2}$ & $\mathbf{2 0 1 3}$ & $\mathbf{2 0 1 2}$ & $\mathbf{2 0 1 3}$ & $\mathbf{2 0 1 2}$ & $\mathbf{2 0 1 3}$ \\
\hline min & 21,4 & 16,7 & 21,35 & 20,77 & 1,22 & 1,47 & 84,60 & 80,54 \\
\hline max & 29,0 & 25,1 & 25,73 & 26,12 & 1,90 & 2,13 & 87,60 & 86,03 \\
\hline srednja & 24,9 & 21,2 & 23,51 & 23,58 & 1,52 & 1,84 & 85,96 & 83,49 \\
\hline LSD & \multicolumn{2}{c}{0,01} & \multicolumn{2}{c}{ n.s. } & \multicolumn{2}{c}{0,01} & & 0,01 \\
\hline
\end{tabular}

Prosječne vrijednosti ukupne suhe tvari (ST) u plodu maraske na plantaži "Vlačine" (Maraska d.d.), kretale su se u vrlo širokom rasponu od 21,4 do 29,0\% u 2012., te od 16,7 do $25,1 \%$ u 2013. godini. Značajno veće prosječne vrijednosti ukupne ST u plodu višnje Maraske za cijeli voćnjak utvrđene su u 2012. (24,9\%) u odnosu na 2013. godinu (21,2\%), dok razlike u količinama vodotopive ST nisu bile signifikantne. Utvrđene vrijednosti ukupne ST u plodu maraske bile su značajno veće od vrijednosti ukupne ST (16,9\% ukupne ST) u drugim vrstama višanja koje navode Money i Christian (1958), a usporedive su s vrijednostima (21,0-23,0\% ST) koje iznosi Medin (1971), te s vrijednostima (16,77 - 27,27\% ST) koje su utvrdili Pedisić i sur. (2007) u plodovima maraske za ekotip Recta na području Zadra i Splita u 2005. godini. Veće vrijednosti ukupne suhe tvari u 2012. u odnosu na 2013. godinu mogu se dovesti u svezu s različitim klimatskim prilikama u godinama istraživanja. $\mathrm{Na}$ širem zadarskom području u jesensko-zimskim mjesecima padne 50 do $65 \%$ ukupnih oborina, a u proljeće i ljeto 35 do $50 \%$ oborina. U 2012. godini ukupna količina oborina u prvih šest mjeseci $(207,9 \mathrm{~mm})$, bila je 3,3 puta niža u odnosu na količinu oborina $(725,7$ $\mathrm{mm}$ ) utvrđenu u 2013. godini, dok su srednje mjesečne temperature u fazi zriobe (lipanj) bile za $3,0^{\circ} \mathrm{C}$ niže u 2013. u odnosu na 2012. godinu. Za razliku od ukupne suhe tvari, značajno veće vrijednosti ukupnih kiselina utvrđene su u 2013. (1,84\%) u odnosu na 2012. godinu (1,52\%), tablica 1 . Utvrđene vrijednosti ukupnih kiselina u obje godine istraživanja u skladu su sa podatcima (1,8\% ukupnih kiselina) koje iznosi Medin, (1971), a nešto niže od vrijednosti (1,88 - 2,72 \% ukupnih kiselina) koje su utvrdili Pedisić i sur. (2007.) za područje Zadra i Splita u plodu maraske, ekotip Recta. Udio mesa u plodovima značajno se razlikovao ovisno o godini istraživanja. Veći prosječni udio mesa (86,0\%) utvrđen je u 2012. u odnosu na vlažniju 2013. godinu (84,0 \%), što je u skladu s navodima Puškara (2002) kako je utjecaj ekotipa na udio mesa u plodu veći od utjecaja abiotskih čimbenika.

Analizom biološki aktivnih spojeva i antioksidativnog kapaciteta (tablica 2) utvrđene su značajno veće vrijednosti ukupnih polifenola i antioksidativnog kapaciteta te niže vrijednosti ukupnih antocijana u 2012. u odnosu na 2013. godinu, što se može dovesti u svezu sa značajno većim količinama oborina i nižim temperaturama u fazi zriobe plodova u 2013. godini. 
Tablica 2. Polifenoli, antocijani i antioksidativni kapacitet ploda maraske, 2012-2013

\begin{tabular}{|c|c|c|c|c|c|c|}
\hline \multirow[b]{2}{*}{ godina } & \multicolumn{2}{|c|}{$\begin{array}{l}\text { Ukupni polifenoli } \\
\text { mg/100 g GAE* }\end{array}$} & \multicolumn{2}{|c|}{$\begin{array}{l}\text { Ukupni antocijani } \\
\text { mg/100 g CGE** }\end{array}$} & \multicolumn{2}{|c|}{$\begin{array}{c}\text { Antioksidativni kapacitet } \\
\text { mmol/100 g TEAC*** }\end{array}$} \\
\hline & 2012 & 2013 & 2012 & 2013 & 2012 & 2013 \\
\hline $\min$ & 391,4 & 336,0 & 39,5 & 51,5 & 2,89 & 2,04 \\
\hline $\max$ & 691,7 & 538,7 & 69,8 & 84,5 & 5,22 & 4,62 \\
\hline srednja & 480,5 & 426,0 & 50,3 & 69,1 & 3,64 & 2,94 \\
\hline LSD & \multicolumn{2}{|c|}{0,05} & \multicolumn{2}{|c|}{0,01} & \multicolumn{2}{|c|}{0,05} \\
\hline
\end{tabular}

Količine ukupnih polifenola u plodu maraske kretale su se u rasponu od 391,4 do 691,7 (prosjek 480 mg/100g GAE) u 2012., te od 336,0 do 538,7 (prosjek 430,0 mg/100g GAE) u 2013. godini. Utvrđene vrijednosti ukupnih polifenola, a isto tako i prosječne vrijednosti antioksidativnog kapaciteta $(3,64 \mathrm{mg}$ i $2,94 \mathrm{mg} / 100 \mathrm{~g}$ TEAC) u obje godine istraživanja značajno su veće u odnosu na vrijednosti ukupnih polifenola i antioksidativnog kapaciteta u drugim vrstama višanja, što su u svojim istraživanjima potvrdili i Dragović-Uzelac $i$ sur. (2007). Značajno niže vrijednosti antocijana u 2012. u odnosu na 2013. godinu mogu se objasniti ekstremno visokim temperaturama u fazi zriobe u 2012. godini koje prema literaturnim navodima mogu smanjiti količinu antocijana u plodovima i do 90 \% (Kim i Padilla-Zakour, 2004).

Koeficijenti korelacije $(r=0,98$ i $r=0,72)$ između ukupnih polifenola i antioksidativnog kapaciteta te ukupnih polifenola i antocijana $(r=0,62$ i $r=0,67)$, pokazuju da postoji pozitivna korelacija između ukupnih polifenola i antioksidativnog kapaciteta (grafovi 5 i 6) kao i polifenola i antocijana (grafovi 7 i 8) u obje godine istraživanja. Dobiveni rezultati u suprotnosti su s podacima Pedisić i sur. (2007), koji u svojim istraživanjima nisu utvrdili korelaciju između polifenola i antioksidativnog kapaciteta u plodu maraske. U obje godine ovog istraživanja pozitivna korelacija $(r=0,69$ i $r=0,70)$ utvrđena je i između antocijana i antioksidativnog kapaciteta (grafikoni 9 i 10), što je u skladu s literaturnim navodima da su ukupni polifenoli uz antocijane dobar indikator antioksidativnog kapaciteta (Levaj i sur., 2010).

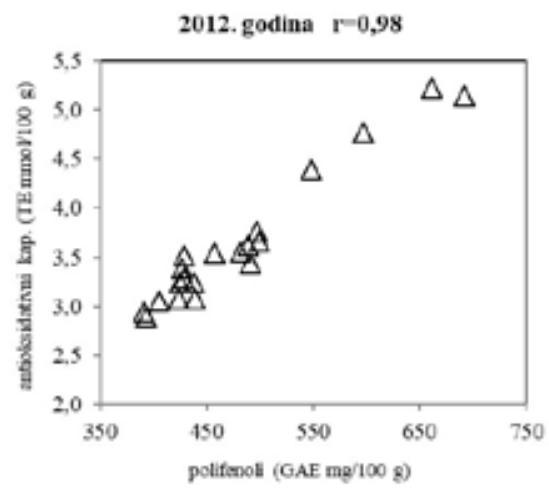

Graf 5. Korelacija između polif. i antiok. kap., 2012

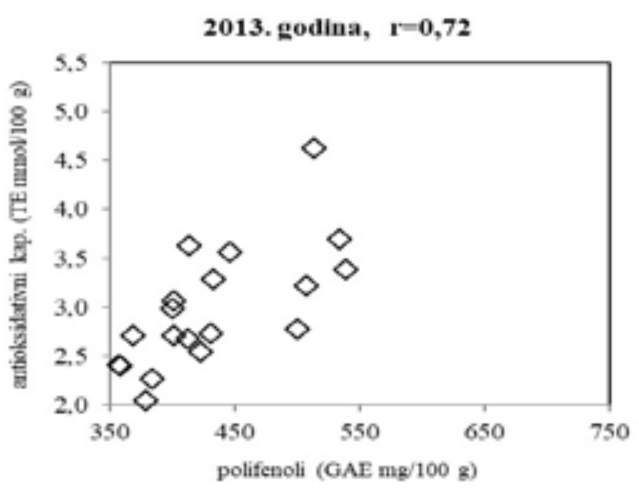

Graf 6. Korelacija između polif. i antiok. kap., 2013 
2012. godina, $1-0,62$

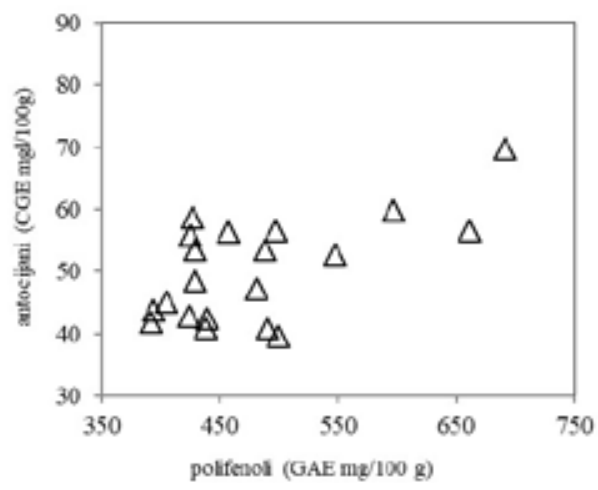

Graf 7. Korelacija između polif. i antocijana, 2012

2012. godina, $r-0,69$

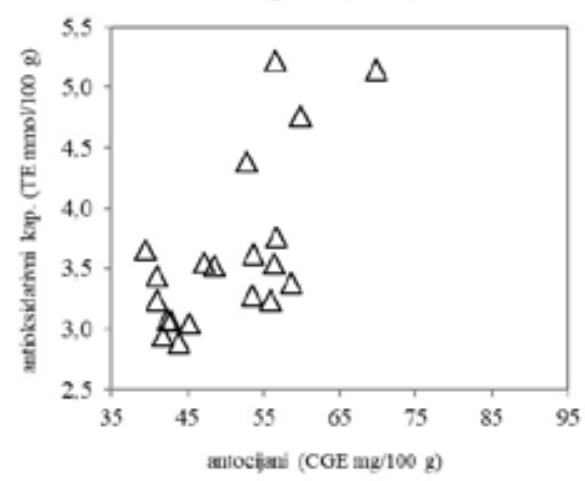

Graf 9. Korelacija između antoc. i antiok. kap., 2012
2013. godina, $r=0,67$

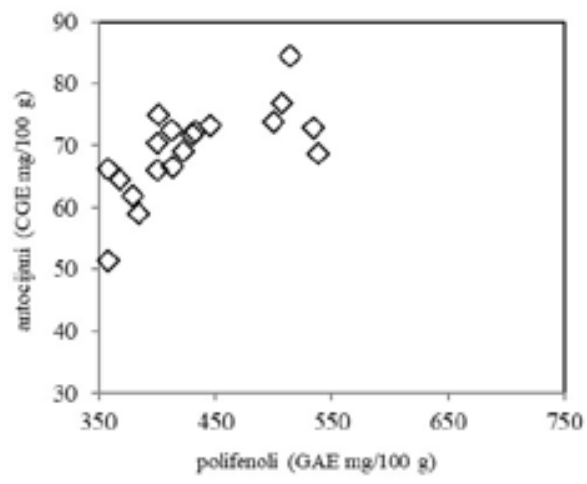

Graf 8. Korelacija između polif. i antocijana, 2013

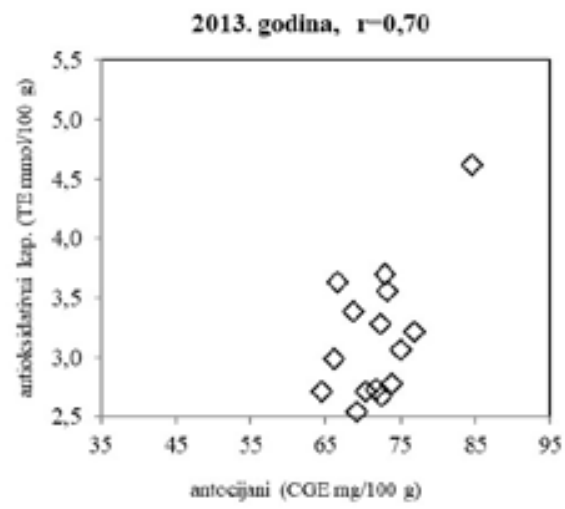

Graf 10. Korelacija između antoc. i antiok. kap., 2013

\section{Zaključak}

Temeljem dobivenih rezultata istraživanja može se zaključiti da postoje značajne razlike u kemijskim svojstvima ploda maraske ovisno o klimatskim uvjetima. Značajno veće vrijednosti ukupne suhe tvari, polifenola te veći antioksidativni kapacitet utvrđeni su u godini s manjom količinom oborina i većim temperaturama, dok su veće vrijednosti ukupnih kiselina i antocijana utvrđene u godini s većom količinom oborina i nižim temperaturama u fazi zriobe plodova.

\section{Literatura}

Arnao, M. B.; Cano, A.; Acosta, M. (2001). The hydrophilic and lipophiliccontribution to total antioxidant activity. Food Chemistry, 73, 239-244.

Brouillard, R. (1982). Chemical structure of anthocyanins. Anthocyanins as Food Colors. P.Markakis (ur.), Academic Press Inc., New York, 1-38.

Burkhardt, S.; Tan, D. X.; Manchester, L. C.; Hardeland, R.; Reiter, R. J. (2001). Detection and quantification of the antioxidant melatonin in Montmorency and Balaton tart cherries (Prunus cerasus). J. Agric. Food Chem., 49, 4898-4902.

Chandra, A.; Nair, M. G.; Lezzoni, A. (1993). Novel process for the isolation and stabilization of antocyanin pigments 
from Montmorency cherry (Prunus Cerasus L.). J. Agric. Food Chem. 41, 1063-1065.

Ćosić, T. (1993). Utjecaj podloge na kemijski sastav lišća i kakvoću ploda Maraske. Hrvatski voćarski glasnik, 2, 1-4.

Dekazos, E. D. (1970). Anthocyanin Pigments in Red Tart Cherries. J. Food Sci., 35, 237-241.

Dragović-Uzelac, V., Bursać Kovačević, D., Levaj, B.,; Pedisić, S., Mezak, M., Tomljenović, A. (2009). Polyphenols and antioxidant capacity in fruits and vegetables commonly consumed in the Croatian diet. Agriculturae conspectus scintificus, 74, 3, 175-179.

Dragović-Uzelac, V., Levaj, B., Bursać, D., Pedisić, S., Radojčić, I., Biško, A. (2007). Total Phenolics and Antioxidant Capacity Assays of Selected Fruits. Agriculturae Conspectus Scietificus, 72, 4, 279-284.

Giusti, M. M., Wrolstad, R. E. (2001). Characterization and measurement of anthocyanins by UV-visible spectroscopy. Current Protocols in Food Analytical Chemistry. R.E. Wrolstad, S.J. Schwartz (ur.). John Wiley \& Sons, Inc. New York, NY. Pogl. 1.2.1-1.2.13.

Kim, D. O., Padilla-Zakour, O. I. (2004). Jam processing effect on phenolics and antioxidant capacity in anthocyaninrich fruits: cherry, plum and raspberry. J Food Sci, 69, 395-400.

Levaj, B., Dragović-Uzelac, V., Delonga, K., Kovačević Ganić, K., Banović, M., Bursać -Kovačević, D. (2010). Polyphenols and volatiles in fruits and jams of two sour cherry cutivars and some berry fruits. Food technology and biotechnology, 48,$4 ; 538$.

Medin, A. (1971). Rast i rodnost Maraske u velikim staništima sjeverne Dalmacije, Zadar.

Medin, A. (1989). Suvremeno voćarstvo u jadranskom području, Zadar.

Money, R. W., Christian, W. A. (1958). Analitical Data of Some Common Fruits. J. Sci. Food Agric. $20,118$.

Ough, C. S., Amerine, M. A. (1988). Phenolic Compounds. Methods for Analysis of Musts and Wines.( $2^{\text {nd }}$ ed.). New York: John Wiley \& Sons Inc.: 196-221.

Pedisić, S., Levaj, B., Dragović-Uzelac, V., Kos, K. (2007). Physicochemical Composition, Phenolic Content and Antioxidant Activity of Sour Cherry cv. Marasca During Ripening. Agriculturae Conspectus Scientificus, 72, 4, $295-300$.

Pedisić, S., Dragović-Uzelac, V., Levaj, B., Škevin, D. (2010). Effects of Maturity and Geographical Region on Anthocyanin Content of Sour Cherries (Prunus cerasus var. Marasca). Food technology and biotechnology, 48, 1; 86-93.

Pravilnik o metodama uzimanja uzoraka te obavljanja kemijskih i fizikalnih analiza radi kontrole kvalitete proizvoda voća i povrća (1983). Službeni list SFRJ br. 29 (Narodne novine 53/91), Zagreb

Saure, M. (1990). External control of anthocyanin formation in apple. Scientia horticulturae, 42, 181-218. 109-119.

Vrsaljko, A. (2010). Taksonomska pripadnost Maraske (Prunus Cerasus var. Maraska). Pomologia croatica. 16, 3-4,

\title{
Chemical composition of sour cherry cv. Marasca fruit in climatic two different years
}

\begin{abstract}
Sour cherry cv. Marasca (Prunus cerasus Cv. Marasca) is one of the most important fruit species of Dalmatia ever since 16th century. Production of the famous liqueur Maraschino began at that time. The areal of the prevalence of marasca is limited mainly to the part of the north and central Dalmatia, from Zadar to Makarska, where the climate and soil allow the achievement of high fruit quality and specific aroma. The investigations were aimed to determine the physico-chemical parameters (total dry matter, water soluble dry matter, total acids and percentage of flesh and endocarp in fruit) and biologically active compounds (total polyphenols, anthocyanins and antioxidant capacity) of the marasca cherry fruit in the climatic two different years (2012 and 2013) on the "Vlačine" (Zadar) plantation. Significantly higher values of total dry matter, total polyphenols and antioxidant capacity were determined in 2012, while in 2013 higher values of total acids and anthocyanins were determined. That can be brought into connection with significantly higher amount of precipitation and lower temperatures in the phase of fruit ripening in 2013. In both years of investigation a positive correlation between the total polyphenols and anthocyanins was determine which confirms the fact that the anthocyanins are dominant polyphenolic compounds in the marasca fruit. Significantly lower values of anthocyanins in 2012. compared to 2013. can be explained by the extremely high temperatures in the stage of maturity in 2012. which, according to the literature, can reduce the amount of anthocyanins up to $90 \%$.
\end{abstract}

Key words: marasca fruit, climatic conditions, polyphenols, anthocyanins, antioxidant capacity. 